Review

\title{
A Science-Informed Ethics for Agricultural Biotechnology
}

Sven Ove Hansson ${ }^{1,2}$

1 Royal Institute of Technology, Royal Institute of Technology (KTH), 10044 Stockholm, Sweden; Email: soh@kth.se

2 Swedish University of Agricultural Sciences (SLU), Box 7070, 75007 Uppsala, Sweden

\section{ABSTRACT}

This overview of ethical issues in plant breeding and agricultural biotechnology puts emphasis on the scientific consensus as the basis for ethical studies and discussions. An introduction is given to major ethical issues in plant breeding, including the selection of socially important breeding goals such as environmental and nutritional improvements, the measures needed to ensure that sufficient priority is given to such breeding goals, potential risks and how they should be weighed against benefits, the interpretation of the precautionary principle, intellectual property rights, and the construction of a labelling system for biotechnological products. Some of the common arguments against agricultural biotechnology are also discussed, among them arguments referring to negative effects of yield increases, the dominance of big companies, and the alleged unnaturalness of biotechnology.

KEYWORDS: breeding goals; food toxicity; gene editing; GMO; intellectual property rights; labelling; naturalness; nutritional improvement; patents; plant breeding; precautionary principle; risk assessment; uncertainty; weed development; yield

\section{INTRODUCTION}

\section{G Open Access}

Received: 13 June 2019

Accepted: 15 July 2019

Published: 19 July 2019

Copyright (c) 2019 by the author(s). Licensee Hapres, London, United Kingdom. This is an open access article distributed under the terms and conditions of Creative Commons Attribution 4.0 International License.
In the early 1980s, the transmission of AIDS through blood transfusions was a major public health concern. To avoid the inadvertent use of infected blood, countries around the world introduced lifetime deferrals of blood donations from men who have sex with men. At the time, this was an adequate measure to reduce the risk of iatrogenic transmission of a deadly disease. However, since then, new test methods for the detection of HIV in blood have been developed [1]. A deferral period is still needed to protect against recently acquired infections that cannot be detected reliably even with the new tests, but lifelong deferral is no longer needed. Many countries have reduced the deferral period to 12 months, and in Canada an initiative has been taken to reduce it to three months [2]. However, many countries still apply lifetime deferral, although it does not provide any additional protection against the 
transmission of HIV. Such policies contribute to the scarcity of donors. They may also be conducive to homophobic sentiments and discrimination $[3,4]$.

"Ideally, precautionary policies would be applied when an uncertainty of risk exists, and its application modified or removed as new evidence is brought to light. Such an approach is rarely taken, however. In transfusion medicine, it has proven politically challenging to reverse a decision that was introduced for the purposes of protecting the public.” (p. 144 in [4])

Does this have anything to do with agricultural biotechnology? Yes, in fact it has, since it teaches us a general lesson on precaution and risk assessment that is highly relevant for the on-going discussion on the ethics of agricultural biotechnology. Section 2 (A Moratorium with a Long Shadow) will show how the insights from the HIV example bear on agricultural biotechnology. Section 3 (Dealing with Risks) discusses the nature of the risks that have to be assessed and managed in plant breeding and biotechnology. Section 4 (The Precautionary Principle) is devoted to the precautionary principle, and Section 5 (Weighing Risks and Benefits) to the weighing of risk and benefits. The selection of breeding goals is discussed in Section 6 (The Selection of Breeding Goals), and intellectual property rights to cultivars and biotechnological methods in Section 7 (Intellectual Property Rights). After this we turn to three common types of arguments against the use of biotechnology in agriculture, namely arguments against yield increases (Section 8, The Yield Argument), against the dominance of big companies (Section 9, The Big $\mathrm{Ag}$ Argument), and against the alleged unnaturalness of biotechnology (Section 10, Naturalness). Labelling and consumers' right to know are discussed in Section 11 (Labelling and Consumers' Rights). Section 12 (Ethical Foundations) discusses how the ethics of agricultural biotechnology should connect with other, more general, approaches to ethics. Section 13 concludes.

\section{A MORATORIUM WITH A LONG SHADOW}

Let us go back to the very beginning of modern biotechnology. In the early 1970s, the prospect of modifying the genetic code was (rightly) seen as a major emerging breakthrough in biological research. Researchers predicted that the new technology could be used not only as a research tool but also for instance in medicine, chemical synthesis, and breeding crops and livestock. But there were also fears. The biochemical mechanisms of gene expression, gene repair etc. were still only understood in a fragmentary way. Scientists worried that the new types of interventions they were trying out in their laboratories might in some way have severe negative effects on living organisms including ourselves. The inadvertent spread of dangerous infectious agents was mentioned as an example, but for the most part, these worries did not 
concern specific and well-defined risks. The major trouble was the general lack of knowledge, which gave rise to fears that there might be unknown, perhaps highly dangerous effects. A typical expression of this sentiment can be found in an article by a medical student, writing in 1978:

"It is the unknown, the dangers that we cannot anticipate and thus guard against, that lie at the heart of the recombinant DNA controversy. Neither the potential risks nor the potential benefits, though highly publicized and much discussed, can be substantiated. No one can be certain of all the consequences of inserting genes from one organism into the genome of another." (p. 183 in [5])

In July 1974, 11 American researchers, headed by Paul Berg, published an open letter in Science and other journals, where they proposed that scientists should "voluntarily defer" two types of experiments with biologically active recombinant DNA molecules. This, they said, was because of "serious concern that some of these artificial recombinant DNA molecules could prove biologically hazardous". The proposed intermission was intended to last "until the potential hazards of such recombinant DNA molecules have been better evaluated or until adequate methods are developed for preventing their spread" [6].

The proposal was well received by colleagues, and a de facto moratorium was implemented. However, this was not a "wait and see" postponement but to a very high degree a "wait and investigate" deferment. The researchers working in the area jointly performed a careful evaluation of the potential dangers of the new technology, and they concluded that these dangers could be specified and understood well enough to be manageable if adequate protective measures were taken. At the Asilomar Conference on Recombinant DNA in February 1975, the moratorium was lifted. Scientists resumed their experiments, applying the safeguards they had agreed upon.

Twenty years later Paul Berg (then a Nobel Prize laureate) and Maxine Singer (another leading biologist) wrote a retrospective paper, in which they concluded that the new technology had revolutionized biological science. Moreover, this had been achieved without any of the harmful effects that they had feared 20 years earlier. They wrote:

"Literally millions of experiments, many even inconceivable in 1975, have been carried out in the last 20 years without incident. No documented hazard to public health has been attributable to the applications of recombinant DNA technology. Moreover, the concern of some that moving DNA among species would breach customary breeding barriers and have profound effects on natural evolutionary processes has substantially disappeared as the science revealed that such exchanges occur in nature.” [7] 
The experiences they referred to included the information obtained from almost a decade of field trials with transgenic plants; the first such field trial was performed in 1986 [8]. The assessment expressed by Berg and Singer in 1995 represented the scientific consensus, which has continuously been strengthened in the near quarter-century since they published this article. The uncertainties that justified the 1974 moratorium have increasingly been replaced by in-depth understanding of various forms of genetic modification, their mechanisms and their consequences, including potential adverse effects.

In my view there can be no doubt that the 1974 moratorium was justified, given the state of knowledge at the time. For instance, genetic modification of plants was then connected with much greater uncertainties than traditional crossbreeding. Today, the contrary is the case. The belief that modern biotechnology is more likely than conventional breeding methods to produce crops with unintended and undesirable consequences can therefore accurately be called a "genomic misconception" [9].

The nature of the genetic changes that are induced with different biotechnological methods are now well-known, and it is also known that the same types of change occur in nature. The changes in the genome that result from the common biotechnological processes (mutagenesis induction, gene transfer from other genomes, and gene editing) have been shown to be very similar to those resulting from natural processes. Small, localized changes in the genome are extremely common in all organisms. The transfer of genes from other species has a major role in the evolution of bacteria and other unicellular organisms. It is less common in multicellular organisms, but it is known to have taken place in some crops: from Agrobacterium to sweet potato and between rice and millet [10-14].

Plant breeders using transgenics or gene editing know with remarkable precision what changes they induce in the DNA, and they can usually also predict the phenotypical correlates. (However, plant metabolism is remarkably complex [15], and even predictions that are based on extensive studies of gene function will have to be carefully checked in empirical studies.) In contrast, crossbreeding is a still genuinely random process, in which it is impossible to know beforehand what combinations of traits will be found in the offspring (particularly if the traits are multi-genic and show quantitative variation).

Plant breeders are now in much the same situation with respect to harmful crops as blood donation centres with respect to HIV infection: Uncertainties that were once pointed out by experts have been replaced by consolidated knowledge. Hence, some previously justified precautions are no longer needed. But just as in transfusion medicine, it has turned out to be "politically challenging to reverse a decision that was introduced for the purposes of protecting the public" (p. 144 in [4]). Anti-GMO activists continue to invoke uncertainties that have since long 
been laid to rest by science [16]. Even more importantly, decision-makers and the public have not assimilated the new information [17]. Unfortunately, this also applies to the ethical literature. Still today, the discussion in scholarly journals on the ethics of agricultural biotechnology is dominated by the misconception that all direct interventions in the genome give rise to ominous uncertainties not affecting other forms of plant breeding. Scientific uncertainties that were conquered and extinguished by successful research several decades ago still have a ghost life in the ethical literature. Sadly, this is only one of several areas in which ethicists have failed to assimilate essential empirical information [18]. As was pointed out by Ari Schick with reference to another such area, namely human enhancement, when bioethical discourse lacks contact with the science, this puts "speculative bioethics at even greater risk of becoming a self-perpetuating programme, unresponsive to the unpredictability that is at the heart of the scientific enterprise, and largely unaccountable for the role it plays within various 'communities of promise [and peril]'” (p. 228 in [19]).

This is, unfortunately, our point of departure. In order to develop a science-informed ethics of agricultural biotechnology we have a considerable amount of "negative work" to perform. In what follows I will show that there is also important "positive work" waiting for us, or in other words: There are important issues that a science-informed ethics of agricultural biotechnology should deal with, issues that have largely been pushed into the background by controversies that have much too little connection with the actual science.

\section{DEALING WITH RISKS}

Agricultural biotechnology and plant breeding are by no means risk-free activities. Plant breeding-with or without modern biotechnology-is connected with risks, most notably with risks of introducing crops and cultivars that create various types of problems. Let us consider two major such potential problems, food toxicity and weediness.

Many food crops have wild ancestors or relatives that contain toxic substances. In some cases, the domesticated variant resulted from breeding that dramatically reduced the toxicity of its ancestors. Potato is one example of this. Plant breeders sometimes perform crossbreeding between a domesticated potato variant and a wild relative that has desirable traits, such as host plant resistance against pests or insects. The outcome of such crossbreeding may very well be a cultivar that has not only acquired the desired trait, but also an increased content of toxic substances. For instance, solanine is a toxic substance that occurs in high concentrations in some wild potato relatives. Solanine is a natural pesticide, which means that it protects the plant from some of its enemies. Therefore, it should be no surprise that resistance breeding sometimes results in increased content of solanine. This is of course a 
problem that potato breeders are well aware of. Nevertheless, there have been cases when potato cultivars with excessive solanine were released (e.g., "Lenape" in the USA), but had to be withdrawn due to their potential negative effects on human health [20,21]. Obviously, this is a type of event that plant breeders should do all they can to avoid. This applies independently of whether they use traditional techniques alone or combine them with one or other form of modern biotechnology. The toxic effect of a gene does not depend on how it entered the plant's genome.

Invasiveness is a major ecological risk in plant breeding. It has two major forms: The crop might itself become invasive; i.e., spread in an uncontrolled way in the wild, or it might form an invasive hybrid with some wild relative. In both cases, a new weed emerges, which can be a threat to both farming and biodiversity. There is considerable experience showing the practical importance of this problem [22]. For instance, weed beets result from hybridization between sugar beet and wild sea beet. This hybrid weed has caused great economic detriment for sugar beet growers in Europe [23,24]. Hybrids between the wild coconut palm and its domesticated variant have completely replaced the original wild variant, which is now extinct [25]. Crosses between the aggressive weed Johnson grass (Sorghum halapense) and cultivated sorghum (Sorghum bicolor) seem to have given rise to particularly difficult forms of Johnson grass [26]. All of these hybrids have originated in cultivars obtained with crossbreeding. There is no doubt that the same problem can also arise with cultivars obtained with modern biotechnology.

The risk of weed development does not depend on the breeding method. Instead it depends on biological factors, foremost on the traits inherent in the original crop and the new traits that it obtains through breeding. The risk of weed development is greatest for crops that already have high survivability in the wild, such as beets, pasture grasses, and ornamental plants [26-29]. Breeding of such plants for traits that may increase fitness in the wild, such as host plant resistance to pathogens and pests, drought tolerance, and adaptation to extreme weather conditions, requires special care. The same applies to breeding of plants for biofuel production, since these crops are bred for properties that may also increase their chances as weed [30].

These and other risks connected with plant breeding and agricultural biotechnology are well known to plant breeders, and they have been discussed in the scientific literature. However, in the ethical literature they are misleadingly attributed to the use of biotechnology in plant breeding.

\section{THE PRECAUTIONARY PRINCIPLE}

There are discussants who would invoke the precautionary principle against the argument of the previous two sections. They would say that the scientific consensus is not the last word, since scientists might be 
wrong (which they have indeed been before). According to the precautionary principle, they would say, we should take measures also against the risks that scientists do not acknowledge.

When discussing such arguments, it is important to make clear what we mean by the precautionary principle. This is a principle that has been written into international agreements, and it is also included in European law and in many national legislations. Let us therefore begin by clarifying its meaning in these official documents. (One may of course wish to have another precautionary principle than the official one. More about that below.)

Contrary to what has often been assumed, as presented in the official documents the precautionary principle is not just a general instruction to be cautious when making decisions. Instead, it is a principle with a much more limited scope, namely the evaluation of uncertain or incomplete scientific evidence. This can be seen for instance in the most influential international proclamation of the principle, which can be found in the Rio Declaration on Environment and Development from June 1992. It says:

"Principle 15. Precautionary principle

In order to protect the environment, the precautionary approach shall be widely applied by States according to their capabilities. Where there are threats of serious or irreversible damage, lack of full scientific certainty shall not be used as a reason for postponing cost-effective measures to prevent environmental degradation.” [31]

In a Communication from 2000 the European Commission stated that the precautionary principle should be applied when there are "reasonable grounds for concern". Whether there are such grounds has to be determined in risk assessments based on scientific information [32]. Similarly, in a White Paper for chemicals policies, the Commission further clarified this standpoint, and presented the precautionary principle as a requirement that "action must be taken even if there is still scientific uncertainty as to the precise nature of the risks" [33]. From these and many other public documents we can conclude that in its official version, the precautionary principle (1) refers specifically to the evaluation of uncertain evidence for decision-making purposes, which is only one of several types of cautious reasoning that we may apply when making decisions, (2) recommends that we do not restrict our attention to known dangers, but also attend to potential dangers for which there is reasonable but insufficient evidence, and (3) requires the use of science to determine if there is such reasonable evidence. The gist of all this is that the precautionary principle of the official documents is sciencebased. It recommends preventive action based on weak but valid scientific evidence of danger, but it does not recommend action based on hunches, suppositions, or fears that have no support in science [34]. If we are going to follow the official documents, then much of the 
argumentation on GMOs that has been coupled to the precautionary principle will lose its relevance.

But, of course, it could be argued that we should mean something else by the "precautionary principle" than how it is defined in the official documents. Some authors have claimed that the precautionary principle requires measures to be taken even when there are only highly implausible suspicions of danger. Interestingly, this is an interpretation that seems to be shared by proponents and opponents of the principle. As an example of the latter, Whelan [35] maintained that the principle requires us to "act on all the remote possibilities in identifying causes of human disease". In her view, the precautionary principle is a dangerous principle since it lets "the distraction of purely hypothetical threats causes us to lose sight of the known or highly probable ones". (For similar views see [36-38].)

But on the other hand, if we want to be on the safe side, what reason could there be not to consider all possible dangers, even those that are not recognized by science as reasonably plausible? In fact, there is a quite compelling such reason, namely that arguments referring to possible dangers can be constructed both for and against almost anything. For instance, think of some foodstuff that you eat. It is possible that it has some serious long-term health effect that scientists have not yet discovered. But the same applies to everything else that you eat. Hence, the mere possibility that your favourite food can have negative health effects is not reason enough to refrain from consuming it. To be worth considering, an argument for doing so will have to show that there is a higher degree of plausibility than the mere possibility of some unknown toxicity, which applies to all foodstuffs. (For a more thorough discussion of mere possibility arguments and how they can be defeated, see $[39,40]$.)

The general lesson to be drawn from this example is that in order to avoid arbitrariness, applications of the precautionary principle have to be triggered by considerations that have a higher degree of credibility than mere possibilities. Consequently, such decisions cannot be triggered by any contention that someone chooses to make, without supporting evidence. We would then be easy victims to the whims, frauds, and hoaxes of charlatans and attention-seekers. For instance, it is very easy to formulate a contention that some foodstuff or other is unhealthy, that one or other vaccine causes one or other disease, etc. The only protection we have against such postulations (and there are in fact quite a few of them in circulation) is to evaluate whether or not there is reasonably credible evidence behind them. And our tool for doing that is science.

Many mere possibilities have in fact been eliminated in this way. One example is the "polywater" scare that was promulgated in 1969. Polywater, or polymerized water, was an alleged substance that would supposedly be produced in certain types of chemical experiments, and then "grow at the expense of normal water under any conditions found 
in the environment," thus replacing all natural water on earth and destroying all life on this planet [41]. Proposals were made to take precautions against this substance, but its alleged properties were highly implausible from a chemical point of view, and it was soon shown not to exist. And of course, polywater is just one of many constructible chemical doomsday stories. As Michael King and co-workers pointed out, "there may be a non-zero possibility that a chemical synthesized in a laboratory may initiate a chain-reaction that obliterates the ozone layer, destroying all life on earth" (p. 151 in [42]). But as these authors also say, "prohibiting all chemical synthesis based on this possibility would be ridiculous" (ibid, p. 152). (Such a prohibition would put an end to all developments of new pharmaceuticals.) There is no credible reason why polywater should be singled out for action among all the logically possible but scientifically highly implausible doomsday scenarios that can be constructed.

Why did science prevail so easily in the polywater case, and why has it been so difficult to make its voice heard in some other cases? On plausible explanation is that polywater had no investors and no ideologues. Unfounded claims usually survive longer if they have either investors who earn money from them or ideologues who need them to support a worldview or a political programme. This may be an important part of the explanation why unfounded claims about agricultural biotechnology have been much more longevous than those about polywater.

\section{WEIGHING RISKS AND BENEFITS}

In the early days of quantitative risk analysis, that is the 1960s and 1970s, some risk analysts claimed that there is an all-purpose limit between acceptable and non-acceptable risk, usually in the form of a probability threshold (p. 717 in [43]). In other words, they assumed that there is "a lower bound on acceptable risk levels, no matter what the associated benefits", such as "a cutoff level of $10^{-6}$ individual lifetime risk [of death]" (p. 257-258 in [44]). This is known as the "de minimis" position in risk regulation. There are several reasons why it is an ethically highly implausible position. Most obviously, is easy to show with examples that even risks with very low probabilities are unjustified if they bring nothing good with them. Generally speaking, risks are by definition undesired, and therefore a risk cannot be justified per se. It has to be justified by an advantage that it is associated with. This is an insight that was gained fairly early in risk analysis, and today it is uncommon to find claims that a risk should be accepted just because it is small (p. 97-98 in [45]). The crucial issue is whether the risk is outweighed by the benefits that it comes with. For example, in the treatment of life-threatening conditions, risks are sometimes taken that would have been unthinkable in the treatment of a less severe disease. In order to cure a cancer, patients have sometimes been exposed to radiation doses that give rise to a risk as high as about $25 \%$ of inducing a new cancer 
(p. 366 in [46]). This would of course have been out of the question if some other efficient therapy were available that had a lower risk of secondary cancer.

From examples like this we can learn at least three important lessons with quite general applicability:

(1) For action-guiding purposes, assessments of risk are not sufficient. Our objects of evaluation should be the available courses of action.

(2) The evaluation of a course of action should include both its advantages and its risks and other disadvantages.

(3) In the end, decisions should be based on a comparison between the courses of action, in which we consider the balance of advantages and disadvantages for each of them.

This may seem trivial, but these principles are far from universally implemented. The European system for assessing new GM-cultivars is based on pure risk assessments rather than on assessments including both the risks and the advantages of the cultivar. Such a practice is difficult to defend. It would seem reasonable to apply stricter criteria of risk for a cultivar with minimal advantages, such as an aesthetic improvement, than for one with substantial advantages, such as pest resistance that will reduce the use of ecologically problematic insecticides.

Even more importantly, much of the discussion about agricultural biotechnology lacks the focus on courses of action that is necessary for action guidance. We have a sweeping discussion about "GMO or not GMO", which often gives the impression that there is a choice between allowing no genetically modified crops or issuing a carte blanche for all such crops. But in practice, decisions will have to be made on another level, namely that of specific cultivars. Such decisions should be based on the actual traits of these cultivars, which means that the outcomes of plant breeding, not the methods used to obtain them, should be decisive. If the introduction of a particular cultivar is on balance beneficial, it does not make sense to oppose its use because there are other cultivars obtained with the same breeding techniques, whose introduction is considered to be harmful. But this is in fact a common type of argument. For example, one of the most common arguments against the introduction of Golden Rice (which will be offered for free to subsistence farmers) is that other genetically modified products "feed the greed of elite corporate families which have no interest in whether a child in Bangladesh goes blind, or a food production system robs indigenous groups of ancient farming techniques which yield bumper crops of non-GM food" [47]. It has also been argued that this product should not be offered to subsistence farmers since its distribution is a "public relations exercise" of the biotech companies with the intention to "pave the way for global approval of other more profitable genetically engineered crops" [48]. Interestingly, this is an argument that only works 
under the unstated assumption that Golden Rice has the intended positive health effects.

In short, each cultivar has to be judged on its own merits. We urgently need to bring down these debates to discussions on individual crops and cultivars and their advantages and disadvantages as parts of the agricultural system. Such a change in focus will also have consequences for those who argue in favour of using biotechnological products. Much of this argumentation has referred to potential traits that reduce the negative environmental impact of farming or improve the nutritional value of its products. And clearly, quite a few such traits seem to be achievable with modern biotechnology [49-51]. However, these potential future crops cannot be used as arguments for the introduction of crops that do not share their attractive properties. The possibility of future crops that survive without irrigation or pesticides is not a valid argument for introducing crops that do not have these properties. The parallel with some of the fallacious arguments against Golden Rice is obvious.

This being said, it should be recognized that a cultivar can have positive environmental effects even if that was not the main purpose with which it was introduced. This applies for instance to GM cultivars with genes from Bacillus thuringiensis (Bt), which confer resistance to important insect pests. A large meta-analysis showed that the use of Bt crops reduced pesticide quantity by on average $42 \%$, while at the same time increasing yields by $25 \%$ and farmer profits by $69 \%$ [52]. In India, the reduction of pesticide use due to Bt cotton has led to a decrease in acute pesticide poisonings among farmers [53].

\section{THE SELECTION OF BREEDING GOALS}

Currently, more than $99 \%$ of the land that is cultivated with GM crops carries crops with either Bacillus thuringiensis (Bt) genes for pest control or genes inducing tolerance to herbicides (p. 563 in [54]; p. 92-94 in [55]). Both of these crop modifications were developed with increased yields as the primary breeding goal (although, as just mentioned, Bt crops have the important environmental advantage of reducing the use of problematic pesticides). Genetic modifications aiming primarily at environmental advantages have been discussed since the earliest days of GM research, but increased yield is still the dominant breeding goal, both in conventional breeding and in breeding employing modern biotechnology. It is reasonable to assume that greater environmental improvements could have been achieved if they had been given higher priority.

Similarly, breeding goals pertaining to nutritional quality have usually had at most a subordinate role. Again, this applies both to conventional and biotechnological breeding. Since the 1960s, the micronutrient contents of the major cereals (rice, wheat, and maize) have decreased. This can be attributed to breeders focusing on yield at the expense of other features such as nutritional quality ([56]; p. 14 in [57]). 
In a recent article, Johnathan Napier and co-workers discuss why GM-crops with nutritional advantages have not yet been introduced on a large scale [54]. Several factors seem to contribute. Improvements in nutritional quality tend to be genetically complex and involve multiple genes. Therefore, such traits are often more difficult to implement in a reliable way than for instance herbicide tolerance. Another important factor is lack of resources. The financial resources and the number of researchers working on Golden Rice have been much smaller than in comparable, commercial, breeding projects. A third factor is the complicated process of establishing freedom to operate; i.e., making sure that the product can be released without infringing patents or other intellectual property rights held by others. Breeding for nutritional improvement is commonly performed by academic researchers, who tend to pay little attention to intellectual property rights in the early stages of their projects. (In Europe, the use of patented methods in the research phase is largely exempted by the research exemptions in patent law). Sorting out and solving these issues at a later occasion can be a both complex and time-consuming undertaking-increasingly so as the intellectual property of agricultural technology is becoming more and more intricate.

"The field has many active parties, all generating their own intellectual property. Several generic problems confront any entity wishing to determine their freedom-to-operate status. First, the patent landscape for plant biotechnological processes is complicated and congested. Second, progress through the patenting process is (understandably, given the volumes) slow, with many complex filings still not at the granted stage after several years. This means that it is often hard to determine the relevance and breadth of a patent because the final scope of the claims has not yet been decreed. Moreover, the acceptance by examiners of some of the broad claims often included in patent applications has considerably reduced over the years, meaning that grants nowadays are more restricted in scope. Unfortunately, this does not apply retrospectively to earlier patents, meaning that some older patents have a reach that would not be granted now.” (p. 565 in [54])

This raises important questions about breeding goals and how they are decided. Ethically valuable breeding goals, such as reduced environmental impact and higher nutritional value, do not seem to have sufficiently high priority in the breeding industry. A comparison can be drawn with the pharmaceutical industry, which has repeatedly been criticized for not prioritizing drugs against tropical diseases or new antibiotics to be used against bacteria strains that are resistant to the old antibiotics [58]. In both cases, questions have to be raised about possible measures to ensure that higher priority is given to research and development in areas of major public interest. Can new incentives for 
industry research be created? Or should more drug development and plant breeding be performed at public universities and research institutes? These are urgent issues with a considerable ethical component.

\section{INTELLECTUAL PROPERTY RIGHTS}

Plant breeding is about as old as agriculture itself, that is, about ten millennia. Until the last one and a half century or so, it was almost entirely performed by the farmers themselves. By repeated use of seed selection, and increasingly also crossbreeding, farmers obtained better and better crop varieties. Considerable ingenuity has been exerted in these activities. Long before the advent of modern science, farmers performed countless experiments to find the best seeds for each locality and to optimize crop rotations schemes and other agricultural practices. Such experiments are still pursued on a massive scale by indigenous subsistence farmers all around the world [18,59]. In industrialized countries, farmers' own plant breeding has for the most part been replaced by the activities of professional plant breeders.

This long tradition of innovation and experimentation includes a welldeveloped custom of learning from each other, and it has no use for intellectual property rights. (The first patents emerged in the Late Middle Ages, and concerned the products of urban craftspeople [60].) Crop farming has traditionally been based on saving and sharing seeds. Saving seeds from this year's harvest is necessary to be able to get a harvest the next year as well. Sharing seeds with other farmers is the major way in which innovations are disseminated. Seed sharing also increases the genetic variation available to the farmer, which is essential for successful plant breeding.

All this was changed through the introduction of hybrid seeds, by which is (in this context) meant seeds that have been obtained through crossing of two inbred lines. In the 1920s, American plant breeders developed hybrid seeds that gave rise to plants with much better agricultural properties than either of the two inbred lines from which they were obtained. However, if seeds from this first generation were used to grow a second generation, then the result would be a much deteriorated crop. This was a commercial masterstroke. Since hybrid seeds were only good for the first generation, farmers had to buy new seeds for every sowing season. The first hybrid corn seed was put on the market in 1926. Already in the early 1940s, most of the corn grown on US farms had germinated from hybrid seeds (p. 863-864 in [61]).

It was essential for the seed companies to have a monopoly on the cultivation of the inbred parent lines of their hybrids. American trade secret law gave them that protection. In addition, American legislators took the lead in granting plant breeders patent-like protection of their cultivars. In 1930, the American Congress introduced the first intellectual property rights for plant breeders, but this only applied to crops that were reproduced asexually. In 1970, a new law extended this protection 
to crops that were reproduced sexually, including the hybrid cultivars. In 2001, the Supreme Court adjudicated that all kinds of plants could be subject to patents of the same type as more traditional inventions. This decision provided the basis for patents for GMO cultivars. Similar legislation has been implemented in most other industrialized countries, and it has to a large extent been supported by international agreements.

The purpose of patents is to stimulate innovation. There can be no doubt that in agricultural biotechnology, as in other areas, the patent system has contributed substantially to make expensive research and development commercially profitable. In this way, the patent system has contributed to the development of modern agriculture. However, it is also well known that if patent protection goes too far, then it can stifle important forms of innovation and development. Many authors have claimed that this has been the case for the intellectual property rights to crop cultivars and to the materials and methods used to create them.

In quite a few well-documented cases, large companies have put up legal obstacles against independent research on the crops they own. For instance, seeds have been sold with clauses preventing their use in research comparing them to seeds from other companies. Sometimes, companies have made their seeds available for research, but only under conditions giving them control over the publication of the research outcome (p. 874-875 and 886-887 in [61]). These are practices that impinge severely on the integrity of research and threaten to make it impossible for scientists to comply with the requirements of research ethics. As the editors of Scientific American noted, "when scientists are prevented from examining the raw ingredients in our nation's food supply or from testing the plant material that covers a large portion of the country's agricultural land, the restrictions on free inquiry become dangerous" [62]. This problem appears to be particularly large in the USA, whose patent laws give much less leeway for research use than for instance European legislation [63].

The sheer amount of patents and patent claims in the hands of various companies, persons, and institutions has created a "patent thicket" that leads to increasing transaction costs and an increasing focus on attempts to "invent around" existing patents $[64,65]$. This applies not only to the germplasm itself but increasingly also to the various research tools that are used to process it. Navigation in this thicket is becoming more and more difficult, in particular for researchers in universities and small and medium-sized companies, who often lack the resources and expertise required to identify and perform the legal actions needed to proceed with a particular research project [66,67]. In combination with cumbersome approval procedures, this has led to a situation in which only a few large companies have the resources needed for introducing new crops that are based on biotechnological innovations (p. 224 in [68]). This is an ethically problematic situation not least since universities and smaller companies have a very strong role in socially important breeding 
projects, such as breeding of crops grown by smallholders in poor countries and breeding aimed at environmental improvements, climate adaptation and healthier food products.

In addition to this, the current implementation of patent rights creates problems for farmers, especially subsistence farmers. Due to the limitations imposed by patent holders, poor farmers are required to buy new seeds each year, although it would have been perfectly possible to save seeds for sowing. This can make all the difference between being able or unable to send one's teenage children to school, or between affording and not affording healthcare for one's family. In addition, patent rights hamper the important part of agricultural innovation activities that take place on farms. Traditionally, farmers use saved and exchanged seeds to obtain a varied material for selection in their own on-farm breeding programs (based either on spontaneous pollination or controlled cross-breeding). Barring them from using saved seeds for this purpose counteracts the basic purpose of patent legislation, namely to promote innovation.

In all these ways, the current intellectual property regime for crops puts farmers, in particular in third world countries, in a weak and vulnerable position in relation to large and resourceful companies in industrialized countries. Opponents of modern biotechnology have made this an issue of the technologies that are employed. However, there is nothing in these technologies that necessitates a weakened position for farmers. We need to carefully distinguish what the technology brings from what is brought by the social, legal, and economic conditions under which it has been introduced. We also need to discuss the pros and cons of various remedies as well as alternative arrangements. These are discussions that will have to include a careful ethical analysis.

\section{THE YIELD ARGUMENT}

As already mentioned, plant breeding has a strong focus on yields, irrespectively of the breeding methods used. This focus has often been criticized. The "chase for higher yields" is often the target in discussions about the environmental problems in agriculture. Many discussants see the demands for higher yields as the main underlying problem. They are of course right that some of the technologies employed to increase yields have considerable negative environmental effects. Pesticides have saved many harvests, but they have also caused much damage to nature. In many parts of the world, highly toxic insecticides are still in use, causing severe health problems for the growers and their families, as well as considerable harm to non-target insects, including pollinators such as honeybees, which are essential both for agriculture and for the wild flora. Environmental problems are also created when yields are increased by irrigation beyond the capacity of local water supplies or by fertilization to an extent that leads to eutrophication of surrounding waters. 
But that is only one part of the story. The relationship between yields and the environment is in fact quite complex. There is no direct or unavoidable connection between increased yields and environmental damage. Some measures that increase yields are detrimental to the environment, but yields can also be increased in ways that are positive for the environment. Plant breeding is one of the major means to achieve this. Breeders have contributed cultivars with improved tolerance to environmental stresses such as drought, flooding, high salinity, high and low temperatures, and various pests. And of course, we can serve the same purpose by reducing the large losses that take place in all parts of the food chain.

In discussions on the environmental impact of agriculture, it is important (but sometimes surprisingly difficult) to keep in mind that the global environmental impact of agriculture depends to a large extent on how much area we use for farming. In a long perspective, the cultivated area has increased dramatically. From 1700 to 1990, the global area of cropland is estimated to have increased 5.5-fold, and the area of pasture land 6.6-fold. In 1990, 29\% of the world's forest areas and $49 \%$ of its grasslands, steppes, and savannahs had been transformed into agricultural land [69]. Currently, agriculture is responsible for about $80 \%$ of the world's deforestation (p. 81 in [70]). This dramatic reduction in wildland has a large part in the ongoing loss of species that threatens to substantially decrease the planet's biodiversity [71-73]. Furthermore, deforestation reduces the removal of carbon dioxide from the atmosphere via photosynthesis.

In conclusion, natural habitats are already so curtailed that a further large-scale expansion of farmland is bound to have devastating effects. Therefore, if we improve yields on already cultivated lands in environmentally friendly ways, then this is a double win operation-we reduce the environmental impact in these areas, and at the same time we save wilderness from cultivation. But unfortunately, the most easily available ways to increase yields are often such that have considerable negative effects. In terms of yields, we therefore have a local-global dilemma. Increased yields decrease the need for farmland, which is good for the global environment, but the methods used to achieve this tend to have negative environmental effects in the local areas where the increased yields are obtained.

Much more research is needed to develop agricultural methods that solve or mitigate this dilemma. The most promising approaches seem to be those that combine the saving of pristine areas with the development of highly productive farming systems that employ reserves and other measures to preserve local biodiversity [74]. Plant breeding has the potential to contribute to such solutions by developing environmentally friendly ways to increase crop yields. Resistance breeding can reduce the losses due to pests, and at the same time bring down the use of pesticides. Breeding for improved uptake and use of nitrogen can increase harvests 
and also diminish the use for fertilizers. Breeding for drought tolerance or water-use efficiency can reduce losses due to bad weather, while also decreasing the need for irrigation. Breeding for durability of the harvest reduces food waste. Other interesting plant breeding projects aim at perenniality and more efficient photosynthesis. This raises important issue on the choice of breeding goals. There are strong arguments for replacing the currently dominating breeding goal "higher yields" with "higher yields with methods that reduce the negative environmental impact”. But can such a change in breeding goals be achieved, given the current institutional and economic structure of plant breeding?

\section{THE “BIG AG” ARGUMENT}

One of the most frequently used arguments against agricultural biotechnology is its association with large companies. The argument goes much like this: Currently, the seed industry is dominated by a small number of multinational companies. We have reasons to be worried about the weak position of farmers on an increasingly oligopolistic market. In addition, some of these companies have a deeply problematic history of peddling poisonous pesticides. They sell GM-seeds in order to earn money for their already unreasonably rich owners. Arguments in favour of GMOs serve their interests, which obviously go against the interests of smallholders and consumers. These companies are unscrupulous, and therefore we have every reason to assume that their products are bad. We can call this the Big Ag Argument.

This is very similar to the Big Pharma Argument, which is prominent for instance on the webpages of anti-vax campaigners. It goes like this: The big pharmaceutical companies are irresponsible if not outright evil. They earn money by selling vaccines. Therefore, anyone advocating vaccination is furthering the interests of Big Pharma, and consequently such persons cannot be trusted. The use of vaccines furthers the interests of Big Pharma, which are contrary to the interests of common people, so surely the vaccines are bad for us.

These arguments do not lack convincing power, but they both go wrong in a very serious way. Whether these industries behave irresponsibly is one issue, and the quality and usefulness of their products is another, quite separate issue. Irresponsible business can be conducted either with good or bad products. It may in fact be easier to earn an unreasonable amount of money by selling a product that works than one that does not. Therefore, even if you have good reasons to be highly critical of a company's business practices, it does not follow without further arguments that their products are of inferior quality. The qualities of the products have to be determined on a case-by-case basis, for each individual product. If a company exhibits unacceptable business behaviour, then we should do what it takes to put a stop to that behaviour. But the products they sell will nevertheless have to be judged by their actual properties. 


\section{NATURALNESS}

Much of the opposition to agricultural biotechnology is based on a conception of the technology as "tinkering with Mother Nature on a very deep level", in contrast with "natural breeding" and "natural foods" [75]. It is important to observe that the term "natural" is not used here in quite the same sense that scientists use it for instance when talking about "natural selection" or "naturally occurring substances".

As clarified by Helena Siipi, the notion of naturalness is ambiguous between different interpretations [76]. There is a history-based sense of naturalness in which something is more natural, the less it has been modified or influenced by humans. In that sense, a garden is more natural than a restored ecosystem. There is also a property-based sense of naturalness in which something is natural to the extent that it has the same properties as something that is untouched by human action. In that sense, a (successfully) restored ecosystem can be more natural than a garden.

According to a history-based interpretation of naturalness, a cultivar that has been obtained with biotechnological breeding methods is arguably always less natural than one obtained with more traditional methods. But according to the property-based approach it may be the other way around. A cultivar obtained by a single small change on its genome, for instance through gene editing, may be more similar to the parental cultivar than one obtained from the same parent with conventional breeding methods [77]. Claims about naturalness or unnaturalness are often in need of being spelled out along these lines.

In common usage, the terms "natural" and "unnatural" are to a high degree value-laden. If someone says that the aggressive behaviour of a child, or a food additive, or a dose of radiation, is natural, then this statement is usually an expression of acceptance. Similarly, calling something "unnatural" is typically an expression of renunciation. Phenomena of civilization that we all accept are seldom if ever called unnatural. I never heard anybody call it unnatural to boil contaminated water before drinking it, or to wear eyeglasses. In contrast, pasteurization has been called unnatural, and so, in certain religious circles, has the use of condoms. Hence, to say that something is "unnatural" is often less a statement of fact than a way to say that it is bad. The specific type of badness that is expressed by calling something "unnatural" is at least as teleological as it is biological. Presumably, most of those who condemn homosexuality as "unnatural" would not change their view if it could be proven to them that human beings have a biologically based tendency to homosexuality. Similarly, as pointed out by John Stuart Mill, biologically unfounded claims about what is natural or unnatural for women have often been used for repressive purposes ( $\mathrm{p}$. 276-277 in [78]).

In the same way, claims that GMOs are unnatural tend to be highly value-laden. This explains why a GMO opponent who calls the transfer of 
a resistance gene from wild rice to a rice cultivar "unnatural" will usually not be convinced by the counterargument that the gene could also have been acquired by the cultivar through natural, sexual reproduction. The claim that this transfer is unnatural was not a statement of biological fact, but rather a statement about what is appropriate for humans to do or not to do. A relevant answer to that argument will therefore have to be ethical rather than biological; in other words, it will have to be concerned with the moral justification of performing the genetic modification in question.

\section{LABELLING AND CONSUMERS’ RIGHTS}

Some policy issues concerning food are preferably solved by contents regulations. For instance, foodstuffs containing harmful levels of toxic substances are, for good reasons, usually prohibited. Other food issues are better dealt with through the choice of individual consumers. For such issues, labelling regulations are more appropriate. This is how food allergens are usually dealt with.

Many of the reasons that consumers may have for preferring or avoiding certain food products fall outside of the political sphere (at least in liberal democracies). Religious requirements on food are a matter of personal choice. Therefore, it is inappropriate for governments to introduce regulations that require all the food sold in a country to be kosher or halal, or not to contain pork or beef. Labelling is a more suitable tool for satisfying religious food preferences. There is usually no lack of producers willing to supply foodstuff that satisfies these preferences. In combination with adequate labelling, this will enable the consumers to make the types of food choices they wish to make. Life-style choices that are not connected with religion, such as vegan and vegetarian food choices, are dealt with in the same way. In order to protect the consumer's right to make her own choices, false or misleading claims on the label or elsewhere have to be prohibited. A product that is sold as vegan, vegetarian, kosher, halal, or free from pork must also comply with that description.

As we have already noted, there are no scientifically valid arguments for preventing the consumption of all kinds of food obtained with genetic modification or other biotechnological methods. (There may of course be such arguments for specific food products.) Therefore, these products do not, as a group, qualify for contents regulation. On the other hand, there is currently a sizable proportion of the population who strongly prefer only to consume food that has not been produced with modern biotechnology. The food industry can be expected to offer products satisfying the demands of these consumers, just as it does for consumers following the other life-styles just mentioned. In this case as well, labelling that helps consumers to find the products they want will provide "room for people to follow their own value systems" [79]. 
Labelling of biotechnological products can be either obligatory or voluntary. Obligatory labelling makes it sure that all food products come with a text from which the consumer can determine whether or not it contains material from organisms obtained with certain biotechnological processes. Such a system is already in place in the European Union, Australia, New Zealand, and Japan. In contrast, the US and Canada have voluntary labelling. In current practice, this means that food products not containing such ingredients can, at the producer's discretion, be provided with labelling announcing this.

Voluntary labelling has the advantage of conforming to the how the legislation deals with other lifestyle choices. Furthermore, contrary to obligatory labelling it does not run the risk of giving the wrongful impression that public authorities consider these products to be harmful or problematic in one way or other [80]. Another problem with obligatory labelling is that it is impossible to enforce for some types of biotechnological interventions. With gene editing tools such as CRISPR/Cas9, small changes in the genome can be made that incapacitate a whole gene. There is no way to determine with laboratory analysis whether such a change was obtained with these methods or whether it resulted from a spontaneous (natural) mutation. The only way to know whether a food product contains material from a gene-edited crop is therefore to keep track of this throughout the production chains of all its ingredients, all the way back to the breeder. This may be impossible in some cases, especially if ingredients have been imported from countries with no documentation requirements for gene editing. The introduction of an unenforceable legislation could in this case mislead consumers to base their decisions on incorrect information.

Many countries already have an obligatory labelling system for food products containing GMOs, and an initiative to rescind these laws would probably have slim prospects of success. But on the other hand, some reform of the labelling systems seems to be necessary, not least due the emergence of untraceable gene editing methods, which were not foreseen when the current regulations were worked out. There is a need for careful ethical analysis of the options for reformed labelling regulations.

\section{ETHICAL FOUNDATIONS}

In this overview, the focus has been on identifying ethical issues in agricultural biotechnology and contributing to setting a new agenda for the field, namely an agenda based on the current scientific consensus rather than outdated conceptions of the technology and its alleged uncertainties. Each of the issues identified above is in need of extensive ethical analysis. On what foundations should such an analysis be based?

There are two major types of specialized ethical analysis. One of them can be called fundamental ethics. It has a strong emphasis on the search for comprehensive basic principles for morality. Several moral theories 
have been put forward that purport to contain all the information needed to answer all the ethical questions that we may have. The two most important groups of such theories are the utilitarian and the deontological ones. In utilitarian theories it is assumed that the ethical status of alternative courses of action depends on the value of their outcomes. Consequently, acting rightly consists in choosing an alternative with a maximal degree of goodness (or goodness minus badness). According to deontological theories, morality is based on a set of duties or obligations, and acting rightly consists in satisfying the duties that one has. Both deontological and (in particular) utilitarian theories come in many variants, and there are also several additional classes of moral theories, such as those that are based on rights and on contractual relationships. To put it somewhat bluntly, moral philosophers tend to agree that one of the many available moral theories is the one and only, correct theory. However, they do not agree on which that theory is.

The other type of ethical analysis is usually called applied ethics. It is devoted to the practical ethical issues that arise in various specialized types of human activities, such as healthcare, research, engineering, agriculture, business management, etc. One might expect applied ethics to proceed largely by applying fundamental moral theories to practical problems, in much the same way that applied mathematicians and physicists apply mathematical and physical theory to practical problems. But in practice, applied ethics is seldom performed in that way. Instead of applying all-encompassing theories like utilitarianism or deontology to solve their problems, applied ethicists tend to appeal either directly to our moral intuitions or to principles developed specifically for the subject-area in question. The reason for this is that in spite of their pretensions of complete coverage, fundamental moral theories have surprisingly little to say on the practical problems to be dealt with in applied ethics. This has become particularly evident in biomedical ethics. Experience shows that the fundamental theory that a moral philosopher adheres to has little or no predictive power for her standpoints in concrete issues in biomedical ethics [81,82]. You can for instance find a utilitarian and a deontologist who agree on most of the ethical issues in healthcare, although they have different underpinnings for their standpoint. Similarly, two adherents of the same moral theory can disagree vehemently in practical moral issues since they apply it in different ways. The reason for this is that moral theories operate on an abstract level, and most practical moral problems cannot be connected in an unequivocal way to principles or standpoints on that level [83].

In medical and healthcare ethics, this problem has been approached with the introduction of so-called mid-level principles, i.e., principles that are general enough to provide guidance for unified and consistent ethical judgments, but do not have the universalist pretensions of moral theories. In the application of an ethical system containing several such mid-level principles, conflicts may arise between the principles. Such 
conflicts cannot be resolved by the resources of the ethical system itself, but have to be dealt with by those who apply it, using their good judgment.

In medical ethics, a system containing four such principles has a dominant standing: autonomy (respect the patient's right to make her own decisions), beneficence (act in the best interests of the patient), non-maleficence (do not harm), and justice (ensure a fair distribution according to medical needs) [84]. Since this ethical system has a strong focus on healthcare, it cannot be directly transferred to other areas, such as agricultural biotechnology. However, promising attempts have been made to adjust it to problems relating to agriculture and food production $[85,86]$. This is certainly an approach with a potential to be helpful in the development of a scientifically informed ethics of agricultural biotechnology.

\section{CONCLUSIONS}

Current debates on agricultural biotechnology are largely fuelled by outdated assumptions on what uncertainties are involved in the use of these technologies. This overview has shown that beyond these debates, there are important issues that a science-informed ethics of plant breeding and agricultural biotechnology has to deal with, such as:

- The selection of breeding goals, a choice that should be guided by the long-term public good and by the interests of smallholders and consumers,

- The implementation of these breeding goals in a system for plant breeding that is currently dominated by large international companies with other priorities,

- The measures that plant breeders need to take in order to prevent the inadvertent release of cultivars with undesired traits, such as toxicity or weediness,

- How the (science-based) precautionary principle should be applied to plant breeding,

- How a food labelling system can ensure adequate information to consumers wishing to avoid foodstuffs obtained with biotechnology, without contributing to unjustified worries concerning these products, and

- How the intellectual property regime can be reformed and/or better applied, in order to empower subsistence farmers and better support innovations that are important for sustainability and food security.

It should be no surprise that all these issues apply to plant breeding in general, whether or not it makes use of modern biotechnology.

\section{CONFLICTS OF INTEREST}

The author declares that he has no conflicts of interest. 


\section{FUNDING}

This research was funded by MISTRA (The Foundation for Strategic Environmental Research), grant number 2013/13 (MISTRA Biotech).

\section{ACKNOWLEDGEMENTS}

I would like to thank the Editor-in-Chief, Rodomiro Ortiz, and the anonymous referees of Crop Breeding, Genetics and Genomics for highly useful comments on an earlier version of this article.

\section{REFERENCES}

1. Busch MP, Kleinman SH. Nucleic acid amplification testing of blood donors for transfusion-transmitted infectious diseases. Transfusion. 2000;40(2):143-59.

2. Glover B. Reducing blood donation deferral period for gay men being called 'less discriminatory'. Canadian blood services has requested deferral be lowered from a year to three months. Available from: https://barrie360.com/reducing-blood-donation-deferral-period-for-gay-menbeing-called-less-discriminatory. Accessed 2019 Jun 9.

3. Wilson K, Atkinson K, Keelan J. Three Decades of MSM Donor Deferral Policies. What Have We Learned? Int J Infect Dis. 2014;18:1-3.

4. Wilson K, Atkinson KM, Fergusson DA, Brown A, Forster A, Murphy MS, et al. Problems with precaution: the transfusion medicine experience. J Risk Res. 2019;22(2):137-49.

5. $\quad$ Price SL. The little beasts. Mol Cell Biochem. 1978;22:183-92.

6. Berg P, Baltimore D, Boyer HW, Cohen SN, Davis RW, Hogness DS, et al. Potential Biohazards of Recombinant DNA Molecules. Science. 1974;185(4148):303.

7. Berg P, Singer MF. The recombinant DNA controversy: twenty years later. Proc Natl Acad Sci U S A. 1995;92(20):9011-3.

8. James C, Krattiger AF. Global Review of the Field Testing and Commercialization of Transgenic Plants: 1986 to 1995. The First Decade of Crop Biotechnology. Ithaca (NY): ISAAA; 1996. ISAAA Briefs No. 1.

9. Amman K. Genomic misconception: a fresh look at the biosafety of transgenic and conventional crops. A plea for a process agnostic regulation. New Biotechnol. 2014;31(1):1-17.

10. Arber W. Genetic engineering compared to natural genetic variations. New Biotechnol. 2010;27(5):517-21.

11. Custers R, Casacuberta JM, Eriksson D, Sági L, Schiemann J. Genetic Alterations That Do or Do Not Occur Naturally; Consequences for Genome Edited Organisms in the Context of Regulatory Oversight. Front Bioeng Biotechnol. 2019;6:213.

12. Kyndt T, Quispe D, Zhai H, Jarret R, Ghislain M, Liu Q, et al. The genome of cultivated sweet potato contains Agrobacterium T-DNAs with expressed genes: an example of a naturally transgenic food crop. Proc Natl Acad Sci U S A. 2015;112(18):5844-9. 
13. Diao X, Freeling M, Lisch D. Horizontal transfer of a plant transposon. PLoS Biol. 2005;4:e5. doi: 10.1371/journal.pbio.0040005

14. Matveeva TV, Sokornova SV. Biological traits of naturally transgenic plants and their evolutional roles. Russ J Plant Physiol. 2017;64(5):635-48.

15. Keurentjes JJ, Fu J, De Vos CR, Lommen A, Hall RD, Bino RJ, et al. The genetics of plant metabolism. Nature Genet. 2006;38(7):842-9.

16. Ribeiro S. Nobel laureates serving Monsanto and Syngenta. Available from: https://www.etcgroup.org/content/nobel-laureates-serving-monsanto-andsyngenta. Accessed 2016 Jun 9.

17. Hansson SO. How to Be Cautious but Open to Learning: Time to Update Biotechnology and GMO Legislation. Risk Anal. 2016;36(8):1513-7.

18. Hansson SO. Neuroethics for Fantasyland or for the clinic? The limitations of speculative ethics. Camb Q Healthc Ethics. Forthcoming 2019.

19. Schick A. Whereto speculative bioethics? Technological visions and future simulations in a science fictional culture. Med Humanit. 2016;42(4):225-31.

20. Hellenäs KE, Branzell C, Johnsson H, Slanina P. High levels of glycoalkaloids in the established Swedish potato variety Magnum Bonum. J Sci Food Agric. 1995;68:249-55.

21. Valkonen JP, Keskitalo M, Vasara T, Pietilä L, Raman KV. Potato glycoalkaloids: a burden or a blessing? CRC Crit Rev Plant Sci. 1996;15(1):1-20.

22. Ammann K, Jacot Y, Mazyad PR. Weediness in the light of new transgenic crops and their potential hybrids. Zeitschrift für Pflanzenkrankheiten und Pflanzenschutz-Sonderheft. 2000;17:19-29.

23. Boudry P, Broomberg K, Saumitou-Laprade P, Mörchen M, Cuguen J, van Dijk H. Gene escape in transgenic sugar beet: What can be learned from molecular studies of weed beet populations? In: Jones DD, editor. Proceedings of the 3rd International Symposium on the Biosafety Results of Field Tests of Genetically Modified Plants and Microorganisms. Oakland (US): University of California Division of Agriculture and Natural Resources; 1994. p. 75-87.

24. Ellstrand NC. Current knowledge of gene flow in plants: implications for transgene flow. Philos Trans R Soc Lond B Biol Sci. 2003;358(1434):1163-70.

25. Ellstrand NC. Over a decade of crop transgenes out-of-place. In: Wozniak CA, McHughen A, editors. Regulation of Agricultural Biotechnology: The United States and Canada. Berlin (Germany): Springer; 2012. p. 123-35.

26. Ellstrand NC, Hoffman CA. Hybridization as an Avenue of Escape for Engineered Genes. BioScience. 1990;40:438-42.

27. Baker HG. Migration of Weeds. In: Valentine DH, editor. Taxonomy phytogeography and evolution. London (UK): Academic Press; 1972. p. 327-47.

28. Sukopp H, Sukopp U. Ecological long-term effects of cultigens becoming feral and of naturalization of non-native species. Experientia. 1993;49:210-8.

29. Clark EA. Environmental risks of genetic engineering. Euphytica. 2006;148:47-60. 
30. Buddenhagen CE, Chimera C, Clifford P. Assessing biofuel crop invasiveness: a case study. PLoS One. 2009;4(4):e5261.

31. United Nations. Report of the United Nations Conference on Environment and Development, Rio de Janeiro, 3-14 June 1992. Available from: http://www.un.org/documents/ga/conf151/aconf15126-1annex1.htm.

Accessed 2019 July 19.

32. European Commission. Communication from the Commission of 2 February 2000 on the precautionary principle. Available from https://eurlex.europa.eu/LexUriServ/LexUriServ.do?uri=COM:2000:0001:FIN:EN:PDF. Accessed 2019 Jul 18.

33. European Commission. Commission White Paper of 27 February 2001 on the strategy for a future chemicals policy. Available from: http://eurlex.europa.eu/legal-content/EN/TXT/HTML/?uri=URISERV:121275\&from=EN. Accessed 2019 Jun 13.

34. Hansson SO. The Precautionary Principle. In: Möller N, Hansson SO, Holmberg J-E, Rollenhagen C, editors. Handbook of Safety Principles. Hoboken (US): John Wiley \& Sons; 2018. p. 258-83.

35. Whelan EM. Can Too Much Safety be Hazardous? A Critical Look at the 'Precautionary Principle'. Available from: http://www.virginiabiosolids.com/ pdf/Precautionary Principle.pdf. Accessed 2019 Jun 13.

36. Nollkaemper A. "What you risk reveals what you value", and other dilemmas encountered in the legal assaults on risks. In: Freestone D, Hey E, editors. The Precautionary Principle and International Law. Dordrecht (The Netherlands): Kluwer Law International; 1996. p. 73-94.

37. McKinney WJ. Prediction and Rolston's Environmental Ethics: Lessons from the Philosophy of Science. Sci Eng Ethics. 1996;2:429-40.

38. Manson N. The Precautionary Principle, the Catastrophe Argument, and Pascal's Wager. Ends Means. 1999;4(1):12-6.

39. Hansson SO. Great Uncertainty about Small Things. Nanotechnol Chall. 2004;8(2):26-35.

40. Hansson SO. Coping with the unpredictable effects of future technologies. Philos Technol. 2011;24:137-49.

41. Donahoe FJ. ‘Anomalous’ water. Nature. 1969;224:198.

42. Jones G, Whitaker M, King M. Speculative Ethics: Valid Enterprise or Tragic Cul-De-Sac? In: Rudnick A, editor. Bioethics in the 21st Century. Rijeka (Croatia): InTech; 2011. p. 139-58.

43. Rothschild, Victor Risk-The Richard Dimbleby lecture. Listener. 1978;30:715-8.

44. Fiksel J. Toward a de minimis policy in risk regulation. Risk Anal. 1985;5:257-9.

45. Hansson SO. The Ethics of Risk. Ethical Analysis in an uncertain world. New York (US): Palgrave Macmillan; 2013.

46. Hansson SO. Radiation Protection-Sorting Out the Arguments. Philos Technol. 2011;24:363-8.

47. Sarich C. Latin American scientists say Bill Gates’ GMO Golden Rice is a total failure. Available from: https://www.mintpressnews.com/latin-american- 
scientists-say-bill-gates-gmo-golden-rice-total-failure/221007/. Accessed 2019 Jun 10.

48. Chow L. Greenpeace to Nobel Laureates: It’s Not Our Fault Golden Rice Has 'Failed as a Solution'. Available from: https://www.ecowatch.com/greenpeace -to-nobel-laureates-its-not-our-fault-golden-rice-has-failed-1896697050.html. Accessed 2019 Jun 10.

49. Hansson SO, Joelsson K. Crop biotechnology for the environment? J Agric Environ Ethics. 2013;26:759-70.

50. Hansson SO. Agricultural Biotechnology for Health and the Environment. In: Ahuja MR, Ramawat KG, editors. Biotechnology and Biodiversity. Basel (Switzerland): Springer; 2014. p. 67-76.

51. Hansson SO, Åman P, Becker W, De Koning D-J, Lagerkvist CJ, Larsson I, et al. Breeding for public health: A strategy. Trends Food Sci Technol. 2018;80:131-40.

52. Klümper W, Qaim M. A meta-analysis of the impacts of genetically modified crops. PLoS One. 2014;9(11):e111629.

53. Kouser S, Qaim M. Impact of Bt cotton on pesticide poisoning in smallholder agriculture: A panel data analysis. Ecol Econ. 2011;70(11):2105-13.

54. Napier JA, Haslam RP, Tsalavouta M, Sayanova O. The challenges of delivering genetically modified crops with nutritional enhancement traits. Nat Plants. 2019;5:563-7.

55. Global Status of Commercialized Biotech/GM Crops: 2016. Metro Manila (Philippines): ISAAA SEAsiaCenter; 2016. ISAAA Briefs \# 52.

56. DeFries R, Fanzo J, Remans R, Palm C, Wood S, Anderman TL. Metrics for land-scarce agriculture. Science. 2015;349(6245):238-40.

57. Qaim M. Globalisation of agrifood systems and sustainable nutrition. Proc Nutr Soc. 2017;76(1):12-21.

58. Nordrum A. Antibiotic Resistance: Why Aren’t Drug Companies Developing New Medicines To Stop Superbugs? International Business Times. 2015 Mar 3. Available from: https://www.ibtimes.com/antibiotic-resistance-why-arentdrug-companies-developing-new-medicines-stop-1833248. Accessed 2019 Jun 11.

59. Hansson SO. Experiments before science. What science learned from technological experiments. In: Hansson SO, editor. The Role of Technology in Science. Philosophical Perspectives. Dordrecht (The Netherlands): Springer; 2015. p. 81-110.

60. Long PO. Invention, authorship, "intellectual property", and the origin of patents: Notes toward a conceptual history. Technol Cult. 1991;32(4):846-84.

61. Rowe EA. Patents, Genetically Modified Foods, and IP Overreaching. SMU Law Rev. 2011;64:859-93.

62. A Seedy Practice. Sci Am. 2009;301(2):28.

63. Chi-Ham CL, Boettiger S, Figueroa-Balderas R, Bird S, Geoola JN, Zamora P, et al. An intellectual property sharing initiative in agricultural biotechnology: development of broadly accessible technologies for plant transformation. Plant Biotechnol J. 2012;10(5):501-10. 
64. Heller MA, Eisenberg RS. Can patents deter innovation? The anticommons in biomedical research. Science. 1998;280(5364):698-701.

65. Paul R. Tools for Survival: Proposing a Research Exemption for Agricultural Biotechnology Patents to Alleviate Global Hunger. Georget J Poverty Law Policy. 2010;18:103-26.

66. Adenle AA, Sowe SK, Parayil G, Aginam O. Analysis of open source biotechnology in developing countries: An emerging framework for sustainable agriculture. Technol Soc. 2012;34(3):256-69.

67. Pray CE, Naseem A. Intellectual Property Rights on Research Tools: Incentives or Barriers to Innovation? AgBioForum. 2015;8(2-3):108-17.

68. Smyth S, McHughen A. Regulating innovative crop technologies in Canada: the case of regulating genetically modified crops. Plant Biotechnol J. 2008;6(3):213-25.

69. Goldewijk KK. Estimating global land use change over the past 300 years: The HYDE Database. Glob Biogeochem Cycles. 2001;15(2):417-33.

70. Investment and financial flows to address climate change. Bonn (Germany): United Nations Framework Convention on Climate Change (UNFCCC); 2007.

71. Pimm SL, Russell GJ, Gittleman JL, Brooks TM. The future of biodiversity. Science. 1995;269(5222):347-50.

72. Butchart SH, Walpole M, Collen B, van Strien A, Scharlemann JP, Almond RE, et al. Global biodiversity: Indicators of recent declines. Science. 2010;328:1164-8.

73. Pereira HM, Leadley PW, Proença V, Alkemade R, Scharlemann JP, Fernandez-Manjarrés JF, et al. Scenarios for global biodiversity in the 21st century. Science. 2010;330(6010):1496-501.

74. Seppelt R, Beckmann M, Ceauşu S, Cord AF, Gerstner K, Gurevitch J, et al. Harmonizing biodiversity conservation and productivity in the context of increasing demands on landscapes. BioScience. 2016;66(10):890-6.

75. Falconer W. How Safe is Your Animal from GMOs? Available from: https://www.dogsnaturallymagazine.com/how-safe-is-your-animal-fromgmos/700/. Accessed 2019 Jun 11.

76. Siipi H. Dimensions of naturalness. Ethics Environ. 2008;13(1):71-103.

77. Fedoroff N, Haselkorn R, Chassy BM. EPA's proposed biotech policy turns a deaf ear to science. FASEB J. 2011;25(9)2855-7.

78. Mill JS. The Subjection of Women. In: Collected Works of John Stuart Mill. Volume 21. London (UK): Routledge; 1996. p. 59-340.

79. Brom FWA. WTO, Public Reason and Food Public Reasoning in the 'Trade Conflict' on GM-Food. Ethical Theory Moral Pract. 2004;7:417-31.

80. Siipi H, Uusitalo S. Consumer Autonomy and Sufficiency of GMF Labeling. J Agric Environ Ethics. 2008;21:353-69.

81. Kymlicka W. Moral Philosophy and Public Policy: The Case of the New Reproductive Technologies. Bioethics. 1993;7:1-26.

82. Heyd D. Experimenting with embryos: Can philosophy help? Bioethics. 1996;10:292-309.

83. Hansson SO. The Moral Oracle's Test. Ethical Theory Moral Pract. 2014;17:643-51. 
84. Beauchamp TL, Childress JF. Principles of Biomedical Ethics. 7th ed. Oxford (UK): Oxford University Press; 2013.

85. Mepham B, editor. Food Ethics. London (UK): Routledge; 1996.

86. Thompson PB. Agricultural ethics: then and now. Agric Human Values. 2015;32(1):77-85.

How to cite this article:

Hansson SO. A Science-Informed Ethics for Agricultural Biotechnology. Crop Breed Genet Genom. 2019;1:e190006.

https://doi.org/10.20900/cbgg20190006 